\title{
ANALISIS USAHA DAN STRATEGI PENGEMBANGAN INDUSTRI RUMAH TANGGA TEMPE KEDELAI DI KABUPATEN KARANGANYAR
}

\author{
*Diyah Maharani, Kusnandar, Susi Wuri Ani \\ Program Studi Agribisnis Fakultas Pertanian, Universitas Sebelas Maret Surakarta \\ Corresponding author: diyahm@student.uns.ac.id
}

\begin{abstract}
This study aims to analyze the cost, revenue, profits, profitability, analyze internal and external factors, alternative strategies and prioritize strategies for developing the home industry of soybean tempeh in Karanganyar Regency. The data analysis methods used are 1) business analysis to find out the cost, revenue, profit, profitability; 2) IFE Matrix; 3) EFE Matrix; 4) IE Matrix; 5) SWOT Matrix; 6) QSPM Matrix. The results showed that the average cost of the soybean tempeh home industry business in Karanganyar Regency was IDR14,058,002.96 and the average revenue was IDR15,675,000.00 with an average profit of IDR1,616,997.04 and profitability of $11,50 \%$. Analysis of the matrix of IFE home industry in soybean tempeh in Karanganyar is strong with value of 2,877. The results of the EFE matrix also show it is classified as strong with a value of 2,680. The position is in cell 5, namely in the division guarding and maintaining through market penetration strategies and product development strategies. Based on the SWOT matrix, there were eight alternative strategies which were then selected by the four appropriate strategies based on consideration of the IE matrix results, to assess their attractiveness in the QSPM matrix. The highest value of attraction (TAS) of 5,522 is forming institutions or organizations to facilitate access to market, capital, raw material and technology information.
\end{abstract}

Keywords: Tempe Soybean, Business Analysis, Development Strategy

\begin{abstract}
Abstrak: Penelitian ini bertujuan untuk menganalisis besarnya biaya, penerimaan, keuntungan, profitabilitas, menganalisis faktor internal dan eksternal, alternatif strategi serta prioritas strategi pegembangan industri rumah tangga tempe kedelai di Kabupaten Karanganyar. Metode analisis data yang digunakan adalah (1) analisis usaha untuk mengetahui besarnya biaya, penerimaan, keuntungan, profitabilitas (2) Matriks IFE (3) Matriks EFE (4) Matriks IE (5) Matriks SWOT (6) Matriks QSPM. Hasil penelitian menunjukkan bahwa rata-rata biaya selama sebulan pada usaha industri rumah tangga tempe kedelai di Kabupaten Karanganyar sebesar Rp14.058.002,96 dan rata-rata penerimaan Rp15.675.000,00 dengan rata-rata keuntungan adalah Rp1.616.997,04 serta profitabilitas 11,50\%. Analisis matriks IFE industri rumah tangga tempe kedelai di Kabupaten Karanganyar tergolong kuat dengan nilai 2,877. Hasil dari matriks EFE juga menunjukan bahwa industri tersebut tergolong kuat dengan nilai 2,680. Posisi industri tersebut berada pada sel 5 yaitu pada divisi menjaga dan mempertahankan melalui strategi penetrasi pasar dan strategi pengembangan produk. Berdasarkan hasil matriks SWOT diperoleh delapan alternatif strategi yang selanjutnya terpilih empat strategi yang sesuai berdasarkan pertimbangan hasil matriks IE, untuk dinilai daya tariknya pada matriks QSPM. Nilai daya tarik (TAS) tertinggi sebesar 5,522 yaitu membentuk lembaga atau organisasi untuk mempermudah akses informasi pasar, permodalan, bahan baku dan teknologi.
\end{abstract}

Kata Kunci: Tempe Kedelai, Analisis Usaha, Strategi Pengembangan 


\section{PENDAHULUAN}

Sektor pertanian mempunyai peran yang penting dalam pertumbuhan ekonomi suatu negara. Pembangunan pertanian dapat diupayakan melalui pengembangan agribisnis. Menurut Kusnandar et al. (2010) pengembangan agribisnis secara luas menyangkut juga pengembangan agroindustri. Menurut Soekartawi (2006) agroindustri mampu meningkatkan pendapatan pelaku agribisnis, mampu menyerap tenaga kerja, mampu meningkatkan perolehan devisa dan mampu mendorong munculnya industri yang lain. Mengingat jenis industri pertanian yang dikembangkan di pedesaan sangat banyak, maka perlu diprioritaskan pertumbuhan agroindustri yang mampu menangkap efek ganda yang tinggi baik bagi kepentingan pembangunan nasional, pembangunan pedesaan khususnya bagi perekonomian daerah pada umumnya. Hasil penelitian

Setyowati et al. (2012) menyatakan terdapat 47 jenis agroindustri (skala rumah tangga) yang mengolah lebih lanjut produk dari subsektor tanaman pangan, perkebunan, kehutanan, dan perikanan di Kabupaten Karanganyar. Berdasarkan analisis borda, sepuluh besar agroindustri unggulan berdasarkan rankingnya di Kabupaten Karanganyar, rangking satu ditempati oleh tempe. Jumlah industri tempe yang berada di Kabupaten Karanganyar berdasarkan data Dinas Perdagangan, Tenaga Kerja, Koperasi dan UKM Kabupaten Karanganyar (2016) sebanyak 490 unit. Dari 19 kecamatan di Kabupaten Karanganyar, tiga Kecamatan dengan jumlah tertinggi diantaranya Kecamatan Matesih berjumlah 104 unit, Kecamatan Jumantono 85 unit dan Kecamatan Jumapolo 62 unit.

Pengusaha tempe kedelai di Kabupaten Karanganyar dalam menjalankan usahanya menghadapi beberapa kendala, diantaranya harga bahan baku kedelai yang tinggi, teknologi yang digunakan masih sangat sedehana serta skala industri masih dalam skala rumah tangga sehingga dalam perkembanganya mengalami permasalahan internal dan eksternal serta adanya kendala atau masalah tersebut akan memengaruhi besarnya jumlah produksi yang akhirnya juga akan memengaruhi besarnya penerimaan dan keuntungan yang diperoleh. Faktor internal dan eksternal perlu dikelola dengan baik dengan memanfaatkan kekuatan agar memberikan peluang untuk dikembangkan dan mengatasi kelemahan agar tidak menjadi ancaman bagi usaha industri tempe kedelai. Tujuan penelitian ini adalah mengkaji besarnya besarnya biaya penerimaan, keuntungan dan profitabilitas usaha indsutri rumah tangga tempe kedelai di Kabupaten Karanganyar, mengidentifikasi faktor - faktor eksternal dan internal, menentukan alternatif strategi pengembangan serta menentukan prioritas strategi.

\section{METODE PENELITIAN}

Metode dasar yang digunakan dalam penelitian ini adalah metode deskriptif analisis. Penentuan lokasi penelitian ini dilakukan secara purposive yaitu di 3 kecamatan di Kabupaten Karananyar, yaitu Matesih, Jumantono dan Jumapolo dengan pertimbangan Kecamatan tersebut memiliki jumlah pengusaha tempe kedelai tertinggi di Kabupaten Karanganyar. Responden analisis biaya berjumlah 30 responden dan strategi pengembangan menggunakan informan untuk menggumpulkan data dalam penelitian yakni informan kunci (key informan) dengan jumlah 19 orang. Penelitian dilakukan pada bulan Juni 2018.

\section{Metode Analisis Data \\ Analisis Biaya}

Untuk mengetahui biaya total selama produksi dapat diketahui dengan penjumlahan antara total biaya eksplisit dan total biaya implisit. Menurut Purwaningsih (2017) secara matematis dapat dirumuskan sebagai berikut:

$\mathrm{TC}=\mathrm{TCe}+\mathrm{TCi}$

Keterangan:

TC : total biaya (Rp)

TCe : total biaya eksplisit (Rp)

$\mathrm{TCi}$ : total biaya implisit (Rp)

Total penerimaan adalah hasil kali antara total produksi (terjual) dengan harga per satuan produk. Secara matematis dapat dirumuskan sebagai berikut.

$\mathrm{TR}=\mathrm{Q} \times \mathrm{P}$

Keterangan:

TR : total penerimaan (Rp)

$\mathrm{Q} \quad$ : total produksi (bungkus)

$\mathrm{P} \quad$ : harga produk/unit (Rp) 
Keuntungan usaha adalah selisih antara total penerimaan dengan biaya total usaha pembuatan tempe di Kabupaten Karanganyar

$\Pi=\mathrm{TR}-\mathrm{TC}$

Keterangan:

$\pi \quad$ : keuntungan usaha $(\mathrm{Rp})$

TR : penerimaan total $(\mathrm{Rp})$

TC : biaya total (Rp)

Menurut Soekartawi (1995) untuk menghitung profitabilitas, yaitu dengan memperbandingkan antara keuntungan yang diperoleh dengan biaya total yang dikeluarkan yang dinyatakan dalam persen. Besarnya profitabilitas dapat dirumuskan sebagai berikut:

Profitabilitas $=\frac{\pi}{T C} X 100 \%$

Keterangan:

$\pi \quad$ : keuntungan (Rp)

$\mathrm{TC}$ : biaya total $(\mathrm{Rp})$

\section{Strategi Pengembangan}

Metode analisis data pada strategi pengembangan yakni menganalisis Faktor Internal dan Faktor Eksternal, Analisis Posisi Usaha, Analisis Alternatif Strategi dan Analisis Prioritas Strategi. Identifikasi faktor internal bertujuan untuk mengidentifikasi faktor-faktor internal kunci yang menjadi kekuatan dan kelemahan meliputi kondisi keuangan, sumberdaya manusia, kelembagaan, proses produksi, pemasaran dan manajemen. Identifikasi faktor eksternal bertujuan untuk mengidentifikasi faktor-faktor internal kunci yang menjadi peluang dan ancaman meliputi kondisi perekonomian, sosial budaya, pemasok bahan baku, teknologi, pesaing, pasar (konsumen), dan pemerintah pusat. Analisis posisi perusahaan digunakan untuk menentukan posisi industri rumah tangga tempe kedelai di Kabupaten Karanganyar menggunakan matriks IE. Alternatif strategi dengan matriks SWOT untuk menentukan strategi yang ditempuh berdasarkan logika untuk memaksimalkan kekuatan dan peluang, namun secara bersamaan dapat meminimalkan kelemahan dan ancaman perusahaan. Penentuan prioritas strategi dalam pengembangan industri rumah tangga tempe kedelai di Kabupaten Karanganyar menggunakan analisis Matriks QSPM untuk mengevaluasi dan memilih strategi terbaik yang paling cocok diterapkan dalam lingkungan eksternal dan internal.

\section{HASIL DAN PEMBAHASAN}

\section{Karakteristik Responden}

Rata - rata responden dengan umur 52 tahun, umur tersebut masih termasuk dalam kategori kelompok umur produkstif yaknik umur 15-64 tahun. Responden paling banyak berpendidikan SD. Hal ini menunjukkan bahwa hampir sebagian besar pengusaha hanya sampai pada pendidikan tingkat SMP (Sekolah Menengah Pertama), sehingga dapat dikatakan pengetahuan yang dimiliki pengusaha tempe kedelai masih cukup rendah. Jumlah rata-rata anggota keluarga yang dimiliki pengusaha tempe kedelai adalah sebanyak 3 orang. Ratarata tenaga kerja luar keluarga adalah 2 orang, sedangkan jumlah tenaga kerja dalam industri rumah tangga tempe kedelai adalah 2-3 orang. Rata-rata pengusaha tempe kedelai di Kabupaten Karanganyar telah berlangsung selama 20 tahun. Hal ini menunjukkan bahwa pengusaha telah cukup lama dalam menjalankan usahanya, sehingga mereka memiliki cukup pengalaman dalam memproduksi tempe kedelai. Rata-rata jumlah bahan kedelai dalam proses produksi tempe kedelai mulai Mei 2018 adalah sebesar 1.160 $\mathrm{kg}$ dengan rata-rata tiap harinya $38,6 \mathrm{~kg}$. Produksi tersebut cukup besar karena dalam sebulan bisa menghabiskan 1 ton lebih kedelai. Jenis kedelai yang dipakai adalah jenis kedelai impor, kebanyakan menggunakan jenis kedelai BOLA, kedelai USA No. 1. Pengusaha memilih kedelai impor karena mutunya lebih baik dibanding kedelai lokal.

\section{Analisis Usaha Indusri Rumah Tangga Tempe Kedelai di Kabupaten Karanganyar}

Biaya total adalah hasil penjumlahan seluruh biaya implisit dan eksplisit yang dikeluarkan selama proses produksi tempe kedelai sampai dengan dipasarkan. Biaya implisit adalah nilai input yang dimiliki pengusaha yang dilibatkan dalam proses produksi. Biaya implisit dalam industri rumah tangga tempe kedelai, meliputi penyusutan, bunga modal sendiri, dan tenaga kerja dalam keluarga. Biaya eksplisit adalah semua pengeluaran yang dikeluarkan pengusaha tempe kedelai, meliputi biaya bahan baku, tenaga kerja luar keluarga, bahan bakar, pengemasan, transportasi, bahan penolong, Pajak Bumi Bangunan, dan listrik. 
Diyah M., Kusnandar, Susi Wuri A.: Analisis Usaha dan Strategi Pengembangan...

Tabel 1. Rata-Rata Biaya Implisit Industri Rumah Tangga Tempe Kedelai di Kab. Karanganyar Bulan Mei 2018

\begin{tabular}{clrr}
\hline No. & Keterangan & Jumlah (Rp/bulan) & Persentase (\%) \\
\hline 1. & Penyusutan peralatan & $29.912,59$ & 3,8 \\
2. & Bunga modal sendiri & $54.442,46$ & 7.0 \\
3. & Tenaga kerja dalam & $695.000,00$ & 89,2 \\
\hline \multicolumn{5}{c}{ Total } & $779.355,04$ & 100 \\
\hline
\end{tabular}

Sumber: Analisis Data Primer, 2018

Tabel 2. Rata-Rata Biaya Eksplisit Industri Rumah Tangga Tempe Kedelai di Kabupaten Karanganyar Bulan Mei 2018

\begin{tabular}{|c|c|c|c|}
\hline No. & Keterangan & Jumlah (Rp/bulan) & Persentase $(\%)$ \\
\hline 1. & Biaya tenaga kerja luar keluarga & $965.000,00$ & 7,27 \\
\hline 2. & Bahan baku & $8.939 .000,00$ & 67,29 \\
\hline 3. & Bahan Penolong & $43.533,33$ & 0,33 \\
\hline 4. & Bahan bakar & $293.500,00$ & 2,22 \\
\hline 5. & Bahan pengemas & $2.476 .416,67$ & 18,65 \\
\hline 6. & Listrik & $25.033,33$ & 0,19 \\
\hline 7. & Transportasi & $533.933,33$ & 4,03 \\
\hline \multirow[t]{2}{*}{8.} & Biaya Pajak Bumi Bangunan & $2.231,25$ & 0,02 \\
\hline & Total & $13.278 .647,92$ & 100 \\
\hline
\end{tabular}

Sumber: Analisis Data Primer, 2018

Tabel 3. Rata-Rata Biaya Total Industri Rumah Tangga Tempe Kedelai di Kabupaten Karanganyar

\begin{tabular}{llrr}
\hline No. & \multicolumn{1}{c}{ Keterangan } & Jumlah (Rp/bulan) & Persentase $(\%)$ \\
\hline 1. & Biaya Implisit & $779.355,04$ & 5,54 \\
2. & Biaya Eksplisit & $13.278 .647,92$ & 94,46 \\
\hline \multicolumn{5}{r}{} & Total & $14.058 .002,96$ & 100 \\
\hline
\end{tabular}

Sumber: Analisis Data Primer, 2018

Tabel 4. Rata-Rata Penerimaan, Keuntungan, dan Profitabilitas Industri Rumah Tangga Tempe Kedelai di Kabupaten Karanganyar Bulan Mei 2018

\begin{tabular}{|c|c|c|c|c|}
\hline No & Keterangan & Jumlah Produksi (kg) & Harga Per Bungkus (Rp) & Jumlah \\
\hline 1. & Tempe & 53.940 & 816,00 & \\
\hline 2. & Penerimaan & & & $15.675 .000,00$ \\
\hline 3. & Biaya Total & & & $14.058 .002,96$ \\
\hline 4. & Keuntungan & & & $1.616 .997,04$ \\
\hline 5. & Profitabilitas & & & $11,50 \%$ \\
\hline
\end{tabular}

Sumber: Analisis Data Primer, 2018

Biaya implisit yang terbesar, yaitu untuk biaya tenaga kerja dengan rata-rata yang dikelurkan dalam sebulan adalah Rp695.000,00 atau dengan Persentase $89,2 \%$. Jumlah rata-rata tenaga kerja dalam keluarga dalam industri rumah tangga di Kabupaten Karanganyar adalah 2 orang. Biaya eksplisit terbesar dari industri tempe kedelai adalah biaya bahan baku sebesar Rp8.935.000,00 dengan Persentase $67,29 \%$. Jenis kedelai yang digunakan sebagai bahan baku tempe kedelai adalah kedelai impor. Rata-rata penggunan bahan baku kedelai selama sebulan sebanyak $1.160 \mathrm{~kg}$ dengan harga rata-rata $\mathrm{Rp} 7.745,00$ per $\mathrm{kg}$.
Penerimaan merupakan perkalian antara total produk yang dihasilkan dengan harga per biji produk yang dinyatakan dalam satuan rupiah. Rata-rata penerimaan tempe kedelai di Kabupaten Karanganyar selama satu bulan adalah Rp15.675.000,00. Keuntungan yang diperoleh dari industri rumah tangga tempe kedelai merupakan selisih antara penerimaan dengan biaya total. Tabel 4. menunjukkan bahwa penerimaan rata-rata pengusaha tempe kedelai di Kabupaten Karanganyar dalam satu bulan Rp15.675.000,00 dengan total biaya Rp14.058.002,96, sehingga keuntungan ratarata yang diperoleh selama satu bulan adalah 
Rp1.616.997,04. Profitabilitas merupakan hasil bagi antara keuntungan usaha dengan biaya total yang dinyatakan dalam persen, maka dapat diketahui tingkat keuntungan dari industri tempe kedelai. Profitabilitas pada pengusaha tempe kedelai selama satu bulan adalah $11,50 \%$. Hal ini berarti industri rumah tangga tempe kedelai di Kabupaten Karanganyar menguntungkan dan layak untuk dijalankan karena memiliki nilai profitabilitas lebih dari satu. Setiap modal sebesar Rp100,00 yang diinvestasikan akan memperoleh keuntungan sebesar Rp11,50. Misal, awalnya pengusaha tempe kedelai mengeluarkan modal sebesar Rp100.000,00, maka pengusaha akan memperoleh keuntungan sebesar Rp11.500,00.

\section{Faktor Internal dan Eksternal Penembangan Industri Rumah Tangga Tempe Kedelai di Kabupaten Karanganyar}

\section{Faktor Internal}

Analisis faktor internal digunakan untuk menganalisis faktor-faktor internal yang tentunya akan berpengaruh pada pengembangan industri rumah tangga tempe kedelai di Kabupaten Karanganyar. Kekuatan dan kelemahan ini dapat digunakan sebagai bahan pertimbangan dalam penentuan strategi pengembangan. Faktor internal pengembangan industri rumah tangga tempe kedelai di Kabupaten Karanganyar meliputi 6 faktor diantaranya kondisi keuangan, sumber daya manusia, pemasaran, aspek pemasaran juga berhubungan dengan bauran pemasaran, meliputi analisis produk (meliputi macam produk dan mutu/kualitas), analisis harga (meliputi penetapan harga jual) analisis distribusi (meliputi saluran distribusi), dan promosi (meliputi media promosi yang digunakan). Faktor internal selanjutnya produksi atau operasi dan manajemen. Tahap tahap manajemen adalah perencanaan, pengorganisasian, pengawasan dan evaluasi. Faktor internal yang terakhir adalah kelembagaan.

\section{Faktor Eksternal}

Analisis faktor eksternal dilakukan dengan melihat faktor-faktor di luar industri rumah tangga tempe kedelai di Kabupaten Karanganyar untuk mengidentifikasi dan mengevaluasi kecenderungan-kecenderungan yang berada di luar kontrol. Analisis ini berfokus untuk mendapatkan faktor-faktor kunci yang menjadi peluang dan ancaman bagi pengembangan industri rumah tangga tempe kedelai di Kabupaten Karanganyar, sehingga dapat memudahkan untuk menentukan strategistrategi dalam meraih peluang dan menghindari ancaman. Faktor eksternal industri rumah tangga tempe kedelai di Kabupaten Karanganyar meliputi 7 faktor yaitu kondisi perekonomian, sosial budaya, pemerintah pusat, pemasok bahan baku, pasar atau konsumen, teknologi dan persangan.

\section{Matriks IFE-EFE Pengembangan Industri Rumah Tangga Tempe Kedelai di Kabupaten Karanganyar}

Matriks evaluasi internal (Internal Factor Evaluation-IFE Matrix) merupakan alat perumusan strategi dengan meringkas dan menganalisis kekuatan dan kelemahan. Matriks evaluasi eksternal (External Factor Evaluation-EFE) digunakan untuk memungkinkan penyusun strategi untuk meringkas faktor peluang dan ancaman yang ada pada suatu organisasi (David, 2009).

Hasil perhitungan matriks IFE (Internal Factor Evaluation) pada Tabel 5. menunjukkan total skor faktor internal sebesar 2,877> 2,5. Menurut David (2009), total skor diatas 2,5 menunjukkan ciri organisasi yang kuat secara internal. Hasil perhitungan matriks EFE (Eksternal Factor Evaluation) pada Tabel 6. menunjukkan nilai total skor faktor eksternal sebesar 2,518>2,5. Nilai total skor tersebut diatas 2,5 yang berarti posisi eksternal industri rumah tangga tempe kedelai di Kabupaten Karanganayar di kategorikan kuat dengan mampu menarik keuntungan dari peluang yang ada dan meminimalkan pengaruh negatif dari ancaman eksternal. 
Diyah M., Kusnandar, Susi Wuri A.: Analisis Usaha dan Strategi Pengembangan...

Tabel 5. Faktor Internal Industri Rumah Tangga Tempe Kedelai di Kabupaten Karanganyar

\begin{tabular}{|c|c|c|c|}
\hline Faktor Internal & Bobot & Rating & Skor \\
\hline \multicolumn{4}{|l|}{ Kekuatan } \\
\hline 1. Tersedianya tenaga kerja & 0,106 & 3 & 0,318 \\
\hline 2. Kuantitas tempe kedelai yang dihasilkan & 0,091 & 4 & 0,364 \\
\hline 3. Kontinuitas hasil produksi tempe & 0,106 & 4 & 0,424 \\
\hline 4. Usaha mudah dan resiko kecil & 0,087 & 4 & 0,348 \\
\hline 5. Hubungan antara pemasok dan konsumen terjalin dengan baik & 0,098 & 4 & 0,392 \\
\hline 6. Harga produk terjangkau & 0,107 & 3 & 0,321 \\
\hline \multicolumn{4}{|l|}{ Kelemahan } \\
\hline 1. Kualitas dan ketrampilan sumberdaya manusia rendah & 0,076 & 2 & 0,152 \\
\hline 2. Kurang memahami manajemen produksi yang baik & 0,094 & 2 & 0,188 \\
\hline 3. Pengelolaan keuangan pengusaha yang kurang baik & $\mathbf{0 , 1 0 0}$ & 1 & $\mathbf{0 , 1 0 0}$ \\
\hline $\begin{array}{l}\text { 4. Tidak adanya lembaga atau organisasi yang menaungi industri } \\
\text { rumah tangga tempe kedelai }\end{array}$ & 0,135 & 2 & 0,270 \\
\hline Jumlah & 1 & & 2,877 \\
\hline
\end{tabular}

Sumber: Analisis Data Primer, 2018

Tabel 6. Faktor Eksternal Industri Rumah Tangga Tempe Kedelai di Kabupaten Karanganyar

\begin{tabular}{|c|c|c|c|c|}
\hline & Faktor Internal & Bobot & Rating & Skor \\
\hline & \multicolumn{4}{|l|}{ Peluang } \\
\hline 1. & Kondisi lingkungan yang mendukung dan aman & 0,063 & 3 & 0,189 \\
\hline 2 & Pembuangan limbah yang ditangani dengan baik & 0,072 & 3 & 0,216 \\
\hline 3. & Perhatian pemerintah terhadap pengembangan industri tempe & 0,071 & 4 & 0,284 \\
\hline 4. & Kualitas bahan baku yang bagus & 0,070 & 4 & 0,280 \\
\hline 5. & Bahan baku yang mudah didapat & 0,076 & 4 & 0,304 \\
\hline 6. & Permintaan tempe kedelai tinggi & $\mathbf{0 , 0 7 9}$ & 4 & 0,316 \\
\hline 7. & Perkembangan teknologi pengolahan pangan & 0,062 & 2 & 0,124 \\
\hline 8. & Peluang pasar yang luas & 0,069 & 4 & 0,276 \\
\hline 1. & Kenaikan harga sembako & 0,071 & 1 & 0,071 \\
\hline 2. & $\begin{array}{l}\text { Kurangnya peran bimbingan teknis, pendampingan dan } \\
\text { pengawasan dari pemerintah }\end{array}$ & 0,073 & 3 & 0,219 \\
\hline 3. & Terbatasnya bahan baku lokal & 0,069 & 2 & 0,138 \\
\hline 4. & Kualitas kedelai lokal yang kurang baik dibanding impor & 0,074 & 2 & 0,148 \\
\hline 5. & Harga bahan baku dan bahan pengemas fluktuatif & $\mathbf{0 , 0 7 9}$ & 3 & $\mathbf{0 , 2 3 7}$ \\
\hline \multirow[t]{2}{*}{6.} & Adanya produk tempe kedelai dari daerah lain & 0,072 & 2 & 0,144 \\
\hline & Jumlah & 1 & & 2,518 \\
\hline
\end{tabular}

Sumber: Analisis Data Primer, 2010

\section{Matriks IE}

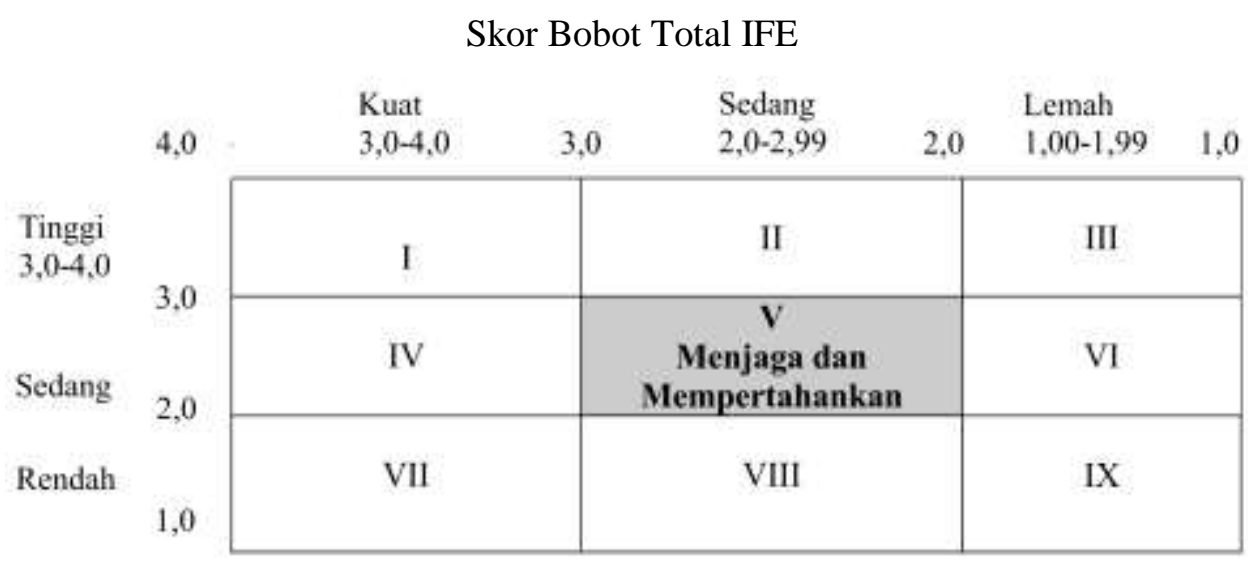

Gambar 1. Matrik IE Industri Rumah Tangga Tempe Kedelai di Kabupaten Karanganyar 
Berdasarkan perolehan hasil dari matriks IFE dan EFE, maka dapat digunakan dalam menyusun matriks IE untuk mengetahui posisi industri rumah tangga tempe kedelai di Kabupaten Karanganyar. Sumbu x dari matriks IE menunjukkan skor bobot IFE industri sebesar 2,877 yaitu posisi internal yang sedang. Sumbu y matriks IE menunjukkan skor bobot total EFE industri sebesar 2,518 yaitu posisi internal yang sedang. Industri rumah tangga tempe kedelai di Kabupaten Karanganyar menempati sel $\mathrm{V}$ yang berarti strategi yang cocok dipakai growth strategy melalui strategi penetrasi pasar dan pengembangan produk. Strategi pertumbuhan (growth strategy) didesain untuk mencapai pertumbuhan, baik dalam penjualan, aset, atau profit, atau kombinasi dari ketiganya. Hal ini dapat dicapai dengan cara menurunkan harga, mengembangkan produk baru, menambah kualitas produk atau jasa, atau meningkatkan akses ke pasar yang lebih luas. Usaha yang dapat dilakukan adalah dengan cara meminimalkan biaya (minimize cost) sehingga dapat meningkatkan profit. Berikut ini gambar posisi industri rumah tangga tempe kedelai di Kabupaten Karanganyar dalam matriks IE.

\section{Perumusan Alternatif Strategi Pengembangan Industri Rumah Tangga Tempe Kedelai di Kabupaten Karangnayar} Perumusan alternatif strategi yang diperlukan dalam mengembangkan industri rumah tangga tempe kedelai di Kabupaten Karanganyar menggunakan analisis matriks SWOT. Matriks SWOT menggambarkan secara jelas bagaimana peluang dan ancaman eksternal dapat dipadukan dengan kekuatan dan kelemahan internal sehingga dihasilkan rumusan strategi pengembangan usaha. Matriks ini menghasilkan empat tipe alternatif strategi, yaitu strategi SO (Strength-Opportunities), WO (Weakness-Opportunities), ST (StrenghtThreat), WT (Weakness-Threat).

Terdapat 8 alternatif strategi pengembangan industri rumah tangga tempe kedelai di Kabupaten Karanganyar yaitu:

1. Menjaga serta meningkatkan kualitas dan kontinuitas produk untuk mempertahankan konsumen yang sudah ada serta memperoleh konsumen baru.

2. Meningkatkan produksi
memanfaatkan tenaga kerja dan perkembangan teknologi untuk memenuhi permintaan.

3. Membentuk lembaga atau organisasi untuk mempermudah akses informasi, pasar, permodalan, bahan baku, dan teknologi.

4. Memperbaiki kualitas SDM dengan memberikan pelatihan berupa manajemen produksi, keuangan, dan adopsi teknologi untuk meningkatkan keterampilan.

5. Mengoptimalkan ketersediaan bahan baku.

6. Menjaga loyalitas konsumen dengan mempertahankan harga yang terjangkau serta kualitas produk.

7. Menjalin komunikasi yang baik antara pengusaha dan pemerintah dalam mengembangkan industri rumah tangga tempe kedelai.

8. Memberikan bimbingan teknis, pendampingan, dan pengawasan untuk meningkatkan kualitas dan keterampilan SDM.

\section{Analisis Prioritas Strategi}

Tahap pencocokkan pada matriks SWOT bertujuan untuk menghasilkan strategi-strategi alternatif, bukan untuk memilih atau menentukan strategi mana yang terbaik. Oleh karena itu, tidak semua strategi yang dikembangkan dalam matriks SWOT akan dipilih. Setelah menganalisis matriks SWOT yang diperoleh delapan alternatif strategi, selanjutnya adalah memilih alternatif strategi terbaik yang paling cocok dengan kondisi internal dan eksternal pada pengembangan industri rumah tangga tempe kedelai di Kabupaten Karanganyar. Pemilihan alternatif tersebut mempertimbangkan dari posisi industri berdasarkan hasil analisis pada matrik IE (Internal Eksternal) yang menghasilkan posisi berada pada sel V. Sel V pada matrik IE yang berarti menjaga dan mempertahankan strategi yang umum digunakan untuk tipe divisi ini adalah penetrasi pasar dan pengembangan produk. Sel V pada matrik IE yang berarti menjaga dan mempertahankan strategi yang umum digunakan untuk tipe divisi ini adalah penetrasi pasar dan pengembangan produk. Berdasarkan pertimbangan tersebut maka terpilihkan empat alternatif strategi yang akan digunakan dalam pemilihan prioritas pada matrik QSPM, yaitu:

1. Menjaga serta meningkatkan kualitas dan kontinuitas produk untuk mempertahankan 
konsumen yang sudah ada, serta memperoleh konsumen baru.

2. Membentuk lembaga atau organisasi untuk mempermudah akses informasi pasar, permodalan, bahan baku, dan teknologi.

3. Menjaga loyalitas konsumen dengan mempertahankan harga yang terjangkau serta kualitas produk.

4. Memperbaiki kualitas SDM dengan memberikan perbaikan pelatihan berupa manajemen produksi, keuangan, dan adopsi teknologi untuk meningkatkan keterampilan.

Tabel 7. Matrix SWOT Pengembangan Industri Rumah Tangga Tempe Kedelai di Kabupaten Karanganyar

\begin{tabular}{|c|c|c|}
\hline Faktor Internal & $\begin{array}{l}\text { Kekuatan-S } \\
\text { 1. Tesedianya tenaga kerja } \\
\text { 2. Kualitas tempe kedelai yang } \\
\text { dihasilkan } \\
\text { 3. Kontinuitas hasil produksi tempe } \\
\text { kedelai } \\
\text { 4. Usaha mudah resiko kecil } \\
\text { 5. Hubungan antar pemasok dan } \\
\text { konsumen terjalin dengan baik } \\
\text { 6. Harga produk terjangkau }\end{array}$ & $\begin{array}{l}\text { Kelemahan-W } \\
\text { 1. Kualitas dan kerampilan } \\
\text { sumber daya manusia yang } \\
\text { rendah } \\
\text { 2. Pengelolaan manajemen } \\
\text { produksi yang kurang } \\
\text { 3. Sistem pengelolaan keuangan } \\
\text { pengusaha yang kurang baik } \\
\text { 4. Tidak ada lembaga atau } \\
\text { organisasi yang menaungi } \\
\text { industri rumah tangga tempe } \\
\text { kedelai }\end{array}$ \\
\hline $\begin{array}{l}\text { Peluang-O } \\
\text { 1. Kondisi lingkungan yang } \\
\text { mendukung dan aman } \\
\text { 2. Pembuangan limbah yang } \\
\text { ditangani dengan baik } \\
\text { 3. Perhatian pemerintah terhadap } \\
\text { pengembangan industri kedelai } \\
\text { 4. Kualitas bahan baku yang bagus } \\
\text { 5. Bahan baku yang mudah didapat } \\
\text { 6. Permintaan tempe kedelai yang } \\
\text { tinggi } \\
\text { 7. Perkembangan teknologi } \\
\text { 8. Peluang pasar yang luas }\end{array}$ & 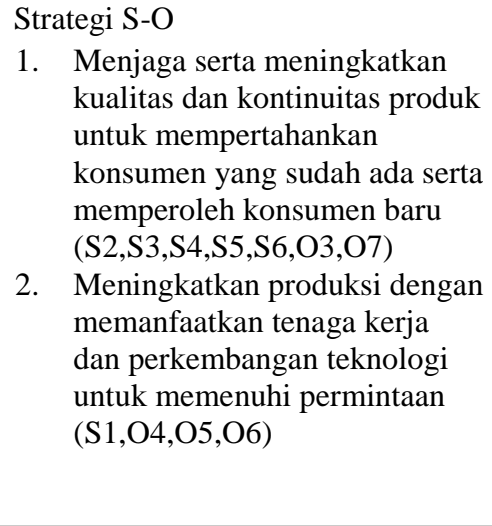 & 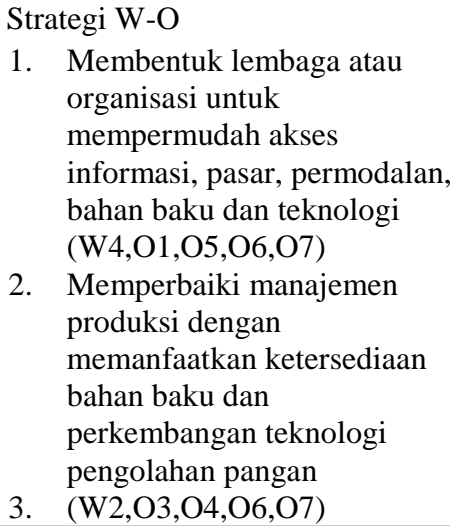 \\
\hline $\begin{array}{l}\text { Ancaman-T } \\
\text { 1. Kenaikan harga sembako } \\
\text { 2. Kurangnya peran bimbingan } \\
\text { teknik, pendampingan dan } \\
\text { pengawasan dari pemerintah } \\
\text { 3. Terbatasnya bahan baku lokal } \\
\text { 4. Kualitas kedelai lokal yang } \\
\text { kuarang baik dibanding impor } \\
\text { 5. Harga bahan baku dan bahan } \\
\text { pengemas fluktuatif } \\
\text { 6. Adanya produk tempe kedelai } \\
\text { dari daerah lain }\end{array}$ & 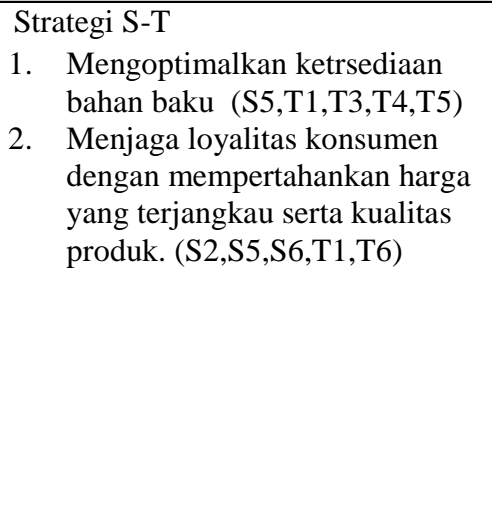 & $\begin{array}{l}\text { Strategi W-T } \\
\text { 1. Menjalin komunikasi yang } \\
\text { baik antara pengusaha dan } \\
\text { pemerintah dalam } \\
\text { mengembangkan industri } \\
\text { rumah tangga tempe kedelai. } \\
\text { (W4,T2,T4) } \\
\text { 2. Memperbaiki kualitas SDM } \\
\text { dengan memberikan } \\
\text { pelatihan berupa manajemen } \\
\text { produksi, keuangan dan } \\
\text { adopsi teknologi untuk } \\
\text { meningkatkan keterampilan. } \\
\text { (W1,W2,W3,T2,T4) }\end{array}$ \\
\hline
\end{tabular}

Sumber: Diolah dan Diadopsi dari Lampiran 
Diyah M., Kusnandar, Susi Wuri A.: Analisis Usaha dan Strategi Pengembangan...

Tabel 8. Matrix QSPM Pengembangan Industri Rumah Tangga Tempe Kedelai di Kabupaten Karanganyar Faktor-faktor kunci

Bobot Alternatif Strategi

\begin{tabular}{llllllll}
\hline \multicolumn{2}{c}{ I } & \multicolumn{2}{c}{ II } & \multicolumn{2}{c}{ III } & & \multicolumn{2}{c}{ IV } \\
\hline AS & TAS & AS & TAS & AS & TAS & AS & TAS
\end{tabular}

Kekuatan

1.Tersedianya tenaga kerja

$\begin{array}{lllllllll}0,106 & 3 & 0,318 & 2 & 0,212 & 1 & 0,106 & 4 & 0,424\end{array}$

2.Kualitas tempe kedelai yang dihasilkan

3.Kontinuitas hasil produksi tempe

4.Usaha mudah

5.Hubungan antara pemasok dan konsumen terjalin dengan baik

6.Harga produk terjangkau

$\begin{array}{llllllllll}0,091 & 4 & 0,364 & 2 & 0,182 & 3 & 0,273 & 1 & 0,091 \\ 0,106 & 4 & 0,424 & 2 & 0,212 & 3 & 0,318 & 1 & 0,106 \\ 0,087 & 4 & 0,348 & 2 & 0,174 & 3 & 0,261 & 1 & 0,087 \\ 0,098 & 2 & 0,196 & 3 & 0,294 & 4 & 0,392 & 1 & 0,098 \\ & & & & & & & & \\ 0,107 & 4 & 0,428 & 1 & 0,107 & 2 & 0,214 & 3 & 0,321\end{array}$

Kelemahan

1.Kualitas dan keterampilan sumber daya manusia rendah

$\begin{array}{ccccccccc}0,076 & 1 & 0,076 & 2 & 0,152 & 3 & 0,228 & 4 & 0,304 \\ 0,094 & 3 & 0,282 & 2 & 0,188 & 1 & 0,094 & 4 & 0,376 \\ 0,100 & 1 & 0,1 & 3 & 0,3 & 2 & 0,2 & 4 & 0,4 \\ 0,135 & 1 & 0,135 & 4 & 0,54 & 2 & 0,27 & 3 & 0,405\end{array}$

4.Tidak ada lembaga atau organisasi yang

menaungi industri rumah tangga tempe kedealai

Peluang

1. Kondisi lingkungan yang mendukung dan aman

2. Pembuangan lmbah yang ditangani dengan baik

3. Perhatian pemerintah terhadap pengembangan industri tempe

$\begin{array}{lllllllll}0,063 & 4 & 0,252 & 2 & 0,126 & 1 & 0,063 & 3 & 0,189 \\ 0,072 & 3 & 0,216 & 2 & 0,144 & 1 & 0,072 & 4 & 0,288 \\ & & & & & & & & \\ 0,071 & 4 & 0,284 & 3 & 0,213 & 1 & 0,071 & 2 & 0,142 \\ 0,070 & 1 & 0,07 & 3 & 0,21 & 4 & 0,28 & 2 & 0,14 \\ 0,076 & 1 & 0,076 & 3 & 0,228 & 4 & 0,304 & 2 & 0,152\end{array}$

4. Kualitas bahan baku

5. Bahan baku yang mudah didapat

Sumber: Diolah dan Diadopsi dari Lampiran

Berdasarkan hasil perhitungan dalam matriks QSPM dapat diketahui nilai daya tarik pada keempat strategi. Total nilai tertinggi diperoleh pada strategi II, yaitu dengan skor 5,509. Strategi II adalah membentuk lembaga atau organisasi untuk mempermudah akses informasi pasar, permodalan, bahan baku, dan teknologi. Selanjutnya, diikuti strategi IV dengan nilai total daya tarik 5,092 yaitu memberikan bimbingan teknis, pendampingan, 
dan pengawasan untuk meningkatkan kualitas dan keterampilan SDM. Kemudian, strategi I dengan nilai total daya tarik 4,94 yaitu menjaga serta meningkatkan kualitas dan kontinuitas produk untuk mempertahankan konsumen yang sudah ada serta memperoleh konsumen baru. Terakhir adalah strategi III dengan nilai total daya tarik 4,459 yaitu menjaga loyalitas konsumen dengan mempertahankan harga yang terjangkau serta kualitas produk.

\section{KESIMPULAN DAN SARAN}

\section{Kesimpulan}

Berdasarkan hasil penelitian dan analisis yang telah dilakukan, maka dapat diambil kesimpulan sebagai berikut :

1. Usaha industri rumah tangga tempe kedelai di Kabupaten Karanganyar dalam proses produksi selama satu bulan (30 hari) mengeluarkan biaya total rata-rata sebesar Rp14.058.002,96 total biaya penerimaan yang diperoleh rata-rata sebesar Rp15.675.000,00 dan keuntungan rata-rata Rp1.616.997,04 sedangkan tingkat profitabilitas usaha adalah sebesar 11,50\%. Dengan demikian berarti usaha industri rumah tangga tempe kedelai di Kabupaten Karanganyar menguntungkan.

2. Faktor-faktor utama internal dan eksternal yang berpengaruh terhadap pengembangan industri rumah tangga tempe kedelai di Kabupaten Karanganyar, yaitu sebagai berikut.

a. Faktor internal yang menjadi kekuatan utama adalah kontinuitas hasil produksi tempe, yaitu dengan skor 0,424 .

b. Faktor internal yang menjadi kelemahan utama adalah sistem pengelolaan keuangan pengusaha yang kurang baik, yaitu dengan skor 0,100 .

c. Faktor eksternal yang menjadi peluang utama adalah permintaan kedelai tinggi, yaitu dengan skor 0,316 .

d. Faktor eksternal yang menjadi ancaman utama adalah harga bahan baku dan bahan pengemas fluktuatif, yaitu dengan skor 0,237 .

3. Industri rumah tangga tempe kedelai di Kabupaten Karanganyar menempati posisi sel $V$ yang berarti menjaga dan mempertahankan, strategi yang sesuai digunakan adalah pengembangan produk dan penetrasi pasar. Berdasarkan pertimbangan tersebut, alternatif strategi pengembangan industri rumah tangga tempe kedelai di Kabupaten Karanganyar adalah:

a. Menjaga serta meningkatkan kualitas dan kontinuitas produk untuk mempertahankan konsumen yang sudah ada, serta memperoleh konsumen baru.

b. Membentuk lembaga atau organisasi untuk mempermudah akses informasi, pasar, permodalan, bahan baku, dan teknologi.

c. Menjaga loyalitas konsumen dengan mempertahankan harga yang terjangkau serta kualitas produk.

d. Memperbaiki kualitas SDM dengan memberikan pelatihan berupa manajemen produksi, keuangan, dan adopsi teknologi untuk meningkatkan keterampilan.

4. Prioritas strategi yang dapat dilakukan oleh industri rumah tangga tempe kedelai di Kabupaten Karanganyar adalah membentuk lembaga atau organisasi untuk mempermudah akses informasi pasar, permodalan, bahan baku, dan teknologi.

\section{Saran}

Hasil penelitian dan analisis yang telah dilakukan, dapat diberikan beberapa saran sebagai berikut:

1. Pemerintah Daerah Kabupaten Karanganyar

a. Pemerintah daerah melalui Dinas Perindustrian, Perdagangan, Koperasi, dan UMKM hendaknya memperhatikan usaha industri skala rumah tangga tempe kedelai di Kabupaten Karanganyar dengan memaksimalkan pelatihan maupun bantuan peralatan pemecah kedelai kepada pengusaha tempe kedelai sehingga dapat meningkatkan produksi dan mengembangkan serta neningkatkan keuntungan.

b. Hendaknya pemerintah daerah memberikan wawasan mengenai sistem pengelolaan keuangan sehingga pengusaha dapat melakukan audit keuangan dengan baik serta memaksimalkan adanya KUR (Kredit Usaha Rakyat) guna mengembangkan usahanya.

c. Memperbaiki kualitas SDM dengan memberikan pelatihan berupa 
manajemen produksi, keuangan dan adopsi teknologi untuk meningkatkan keterampilan

d. Pemerintah daerah mengaktifkan kembali lembaga atau organisasi untuk mempermudah akses informasi pasar, permodalan bahan baku, dan teknologi, menaungi industri rumah tangga tempe kedelai, yaitu KOPTI (Koperasi Tahu Tempe) di Kabupaten Karanganyar.

2. Pengusaha tempe kedelai di Kabupaten Karanganyar

a. Pengusaha tempe kedelai di Kabupaten Karanganyar hendaknya dapat memanfaatkan dengan baik fasilitas yang telah diberikan oleh pemerintah daerah untuk mengembangkan usahanya misalnya dengan memanfaatkan program KUR (Kredit Usaha Rakyat).

b. Pengusaha tempe kedelai hendaknya secara mandiri memperluas wawasan mengenai pembukuan keuangan dan memproduksi tempe kedelai yang sesuai standar serta aktif mengikuti program yang dilakukan pemerintah daerah guna pengembangan usahanya.

\section{DAFTAR PUSTAKA}

BPS. 2016. Kabupaten Karanganyar Dalam Angka 2016. Karanganyar.
David, F. R. 2006. Strategic Management Manajemen Strategis :Konsep. Edisi 10. Jakarta: Salemba Empat. .2009. Manajemen Strategis : Konsep. Edisi 12. Jakarta: Salemba Empat.

Dinas Koperasi dan UMKM Kabupaten Karanganyar. 2016. Data UKM Kabupaten Karanganyar 2016. Karanganyar: Disdagnagkerkop.

Kusnandar, Totok M, Agung W. 2010. Manajemen Agroindustri : Kajian Teori dan Model Kelembagaan Agroindustri Skala Kecil Pedesaan. Surakarta: UNS Press.

Purwaningsih, Y. 2017. Ekonomi Pertanian Pndekatan Teori, Kebijakan, dan Penerapan. Surakarta: UNS Press.

Setyowati, N., Fajarningsih, R. U. dan Adi, K. 2012. Analisis Potensi dan Strategi Pengembangan Jamu Instan di Kabupaten Karanganyar. Caraka Tani, 27(1), 63-74.

Soekartawi. 1995. Analisis Usahatani. Jakarta: Universitas Indonesia-Press. 2006. Agribisnis Teori dan Aplikasi. Jakarta: Rajawali Press. 